\title{
DEVELOPMENT AND CHARACTERISATION OF MISCELLANEOUS CATIONIC SORBENTS BASED ON LIGNOCELLULOSIC GOURD SHELL
}

Goran S. Nikolić1*, Dragana Z. Marković Nikolić², Miloš M. Kostić3 Miloš Durmišević ${ }^{1}$, Milorad D. Cakić ${ }^{1}$

${ }^{1}$ University of Niš, Faculty of Technology, Leskovac, Serbia

2High Technological and Artistic School of Leskovac, Leskovac, Serbia

${ }^{3}$ University of Niš, Faculty of Science and Mathematics, Department of Chemistry, Niš, Serbia

The aim of this study is to develop miscellaneous cationic sorbents based on the lignocellulosic biomass of Lagenaria vulgaris fruit, with the property of efficient sorption of anionic pollutants from aqueous solutions. The lignocellulosic gourd shell (LGS biomass), as a potentially valuable agro-waste, was examined and used for the synthesis of sorbents. The preparation of synthesis precursor (LVAT) was performed by alkaline pretreatment of LGS biomass. Pretreatment under weak alkaline conditions with green carbonate solution was carried out for partial delignification and extraction of depolymerized hemicellulose, thereby achieving higher material porosity and activation of cellulose microfibrils. This activation involves the translation of available -OH functional groups into -ONa form (alkali-cellulose), while maintaining the initial biomass composition. Synthesis of the cationic sorbents was performed in three ways. Different N-reagents, such as tertiary amino and quaternary ammonium compounds, were used in the cation modification of LGS biomass and LVAT precursor, to determine the effects of reagent structure and hydrophobicity on the synthesis outcome, and primarily on the sorption properties of the resulting sorbents. The synthesized cationic sorbents were characterized by physico-chemical methods and tested for the removal of anionic pollutants from water, especially phosphates and nitrates. The various chemical modifications of lignocellulosic biomass provide a scientific contribution to a better understanding of the mechanism of anions sorption on the sorbent surface.
(ORIGINAL SCIENTIFIC PAPER) UDC 662.63:547.458.84:628.193

Keywords: biomass, gourd shell, cationic sorbents, anionic pollutants, wastewater treatment

\section{Introduction}

Municipal and agro-industrial effluents are known to increasingly contain excessive concentrations of various anionic pollutants, primarily phosphates and nitrates. These anionic species pose a serious environmental threat. They are directly responsible for the occurrence of eutrophication and can lead to serious health problems [1]. Taking into consideration the fact that these anionic species are present in the form of soluble salts in water, conventional processes for water treatment (coagulation, sedimentation) have not proven effective for their removal [2]. Modern physico-chemical methods (reverse osmosis, electro-dialysis) and developed methods of biological denitrification $[3,4]$, as well as the application of commercial ion-exchange resins for the removal of nitrates and phosphates from wastewater [5], are not sustainable from a technological and economic aspects. Therefore, further research focused on sorption processes, using cheap agricultural waste as an environmentally friendly sorption material.

Given the facts and current environmental issues, the development of new cationic sorbents has attracted great attention of the scientific community. Researchers have been focused primarily on the advancement of sorption characteristics and selectivity of natural origin sorbents. Numerous studies have investigated the cationic modification of various biomasses [5-7]. Modification of the lignocellulosic material, by introducing specific functional groups, is of interest in obtaining sorbents of enhanced characteristics. For example, cationic functional groups from quaternary ammonium salts increase the sorption capacity of the sorbent for anions, especially the ionexchange capacity [6]. The sorbents with cationic active centers are of particular importance for the treatment of wastewater containing large quantities of various anionic pollutants (nitrates, phosphates, sulfates, cyanides, etc.) $[6,7]$.

The cationic modification of biomass was performed by quaternization of the lignocellulosic material using amino $[8,9]$ or ammonium compounds [10], as well as cationic surfactants [11]. In this regard, various agricultural by-products were examined: wheat straw, sugarcane, rice husk, corn grain, sawdust, etc. [12-16]. However, there is

\footnotetext{
** Author address: Prof. dr Goran Nikolić, Faculty od Technology, 16000 Leskovac, Bulevar oslobodjenja 124, Serbia

E-mail: goranchem_yu@yahoo.com

The manuscript received: November, 04, 2019.

Paper accepted: November, 20, 2019.
} 
insufficient data in the available literature on the use of the gourd shell as a sorbent for anionic pollutants. Gourd shell has been examined generally as a sorbent for the removal of heavy metals from water, in its native form [17], or in the form of some chemically modified (xanthated, sulfonated and methylsulfonated) sorbents [18-21]. More recent studies have focused on the removal of other pollutants from aqueous solutions, such as dyes [22], herbicides [23], and pharmaceutical substances [24]. For that reason, special attention has been paid to the development of new cationic sorbents through chemical modification of the lignocellulosic gourd shell (LGS biomass), a plant material of Lagenaria vulgaris fruit that has not been used for these before.

Due to its nutritional and medicinal features, Lagenaria vulgaris is being grown in many countries around world, which is a good prerequisite for emergence of significant amounts of gourd shell as a potentially valuable agrowaste [25-27]. The shell of Lagenaria vulgaris fruit is characterized by its lignocellulosic composition, extremely compact and solid structure in technical terms, a porous structure, as well as by low ash content and high volume mass. Tests have shown that biomass based on Lagenaria vulgaris, as well as its modified products, do not swell in water and are easily separated from the aqueous phase after treatment [17]. These are very important properties of precursor for sorbent synthesis, which are not found in most other lignocellulosic biomasses.

The complex three-dimensional cross-linked structure of the lignocellulosic material, where lignin is intertwined with cellulose and hemicellulose molecules (Figure 1), allows LGS biomass to have a pronounced hardness and chemical stability [28]. These biomass properties do not favor the process of further modification for the development of cationic sorbents. In this regard, biomass destruction and partial delignification by the pretreatment process, prior to the process of targeted synthesis of an adequate sorbent, are desirable. Bearing in mind that the efficiency of the applied pretreatment process often depends on the starting material nature, physico-chemical characterization of LGS biomass should be performed first. This analysis may indicate the choice of the appropriate biomass modification method (with or without chemical pretreatment), as well as the optimization of the process parameters of sorbent synthesis of typical morphology, through suitable functionalization of the precursor surface.

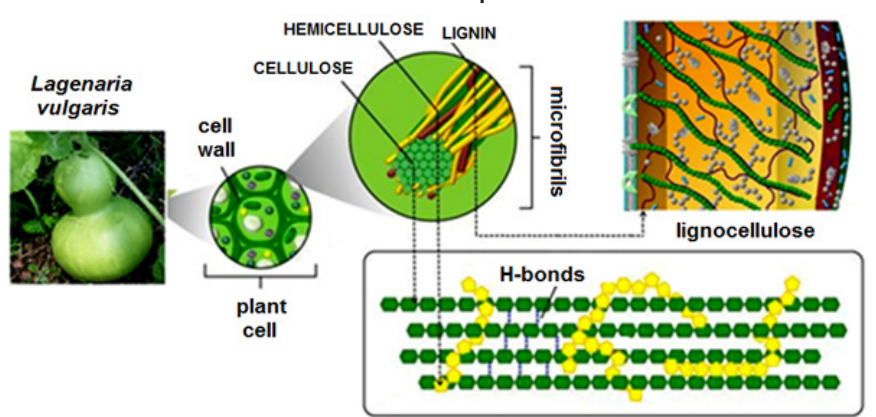

Figure 1. Cell wall model of lignocellulosic biomass with the main structural elements(cellulose, hemicellulose and lignin) [29]
The LGS biomass is characterized by its chemical composition, since it contains - $\mathrm{OH}$ groups as the main functional groups on glucopyranose units of cellulose, which are easily susceptible to various chemical reactions. In order to synthesize the cationic sorbents, studies of chemical modification of LGS biomass have focused on the ammonolysis of alkali-treated or etherified cellulose, as well as the grafting of the cationic surfactant on the lignocellulosic skeleton of biomass. The cationically modified products obtained are primarily expected to have a high sorption capacity for various anionic species. In this regard, the optimization of synthesis parameters and assessment of the product sorption capacity for the nitrate and phosphate anions are of particular importance. Feedback on the influence of process parameters on the formation, amount, and type of active sorption centers is important for improving the efficiency and selectivity of the sorption process of anionic species. Nitrate and phosphate sorption tests in a mixture with other anionic species may be of assistance in the application of these cationic sorbents under real conditions of municipal or industrial wastewater treatment.

\section{Experimental}

\section{Reagents}

All inorganic reagents $\left(\mathrm{HCl}, \mathrm{NaOH}, \mathrm{KNO}_{3}\right.$ and $\left.\mathrm{KH}_{2} \mathrm{PO}_{4}\right)$ used in experiments for the preparation of working solutions or adjustment of $\mathrm{pH}$ and ionic strength were of analytical grade (Merck, Germany). Organic reagents used to modify LGS biomass, such as pyridine (PIR), N,N-dimethylformamide (DMF), epichlorohydrin ( $\mathrm{ECH}, \geq 99 \%$ ) and trimethylamine (TMA, $40 \mathrm{wt} \%$ aqueous solution), were purchased from Sigma-Aldrich Chemie $\mathrm{GmbH}$. For the synthesis of cationic sorbents, less toxic reagents such as $\mathrm{N}$-(3-chloro-2-hydroxypropyl)-trimethylammonium chloride (CHMAC, 65 wt\% aqueous solution, density of $1.154 \mathrm{~g} \mathrm{~cm}^{-3}$ ) and cetyltrimethylammonium chloride (CTAC, 25 wt\% solution, density of $0.968 \mathrm{~g} \mathrm{~cm}^{-3}$ ) were used. Both quaternary reagents (Sigma-Aldrich Chemie $\mathrm{GmbH}$ ) were selected as better and safer options.

\section{Stock and model solutions}

All solutions were prepared with deionized water (18 $\mathrm{M} \Omega$ ), which was also used to rinse the obtained products. A stock phosphate solution $\left(1000 \mu \mathrm{g} \mathrm{P} \mathrm{cm}{ }^{-3}\right)$ was obtained by dissolving $4.3934 \mathrm{~g}$ of pure $\mathrm{KH}_{2} \mathrm{PO}_{4}$ (dried in an oven at $105^{\circ} \mathrm{C}$ for $24 \mathrm{~h}$ ) in $1 \mathrm{dm}^{3}$ of deionized water. Standard working phosphate solutions $\left(10 \mathrm{mg} \mathrm{P} \mathrm{dm}^{-3}\right)$ for sorption experiments were prepared immediately before use, by appropriate dilution of the stock solution. The stock nitrate solution (100 $\mu \mathrm{g} \mathrm{N} \mathrm{cm}^{-3}$ ) was obtained by dissolving $0.7218 \mathrm{~g}$ of pure $\mathrm{KNO}_{3}$ (dried in an oven at $105{ }^{\circ} \mathrm{C}$ for $24 \mathrm{~h}$ ) in $1 \mathrm{dm}^{3}$ of deionized water and then stabilized with $2 \mathrm{~cm}^{3}$ of chloroform. Standard solutions for the calibration chart ( $\left.<10 \mathrm{mg} \mathrm{N} \mathrm{dm}^{-3}\right)$, as well as the working solution for sorption experiments (10 $\mathrm{mg} \mathrm{N} \mathrm{dm}^{-3}$ ), were prepared by diluting the stock solution to the de- 
sired concentration. All standard solutions were stored in the refrigerator $\left(\right.$ at $+4{ }^{\circ} \mathrm{C}$ ) until use.

\section{Material}

As the raw material for the preparation of cationic sorbent, the naturally dried gourd shell (L. vulgaris) was used. The harvested fruits was mechanically cleansed from the pulp and naturally dried for 12 months. The dried shell was ground into pieces of 1 to $2 \mathrm{~cm}$ in size, which are rinsed repeatedly with deionized water to remove dust and rough surface impurities. After drying in an oven $\left(24 \mathrm{~h}\right.$ at $\left.60{ }^{\circ} \mathrm{C}\right)$, the material was ground with a laboratory blender and then passed through standard steel sieves to obtain a fraction of uniform particle size in the range of $400-800 \mu \mathrm{m}$. The prepared LGS material was stored in sealed polyethylene containers (protected from moisture) until use.

\section{Alkaline pretreatment of biomass}

Alkaline pretreatment of gourd shell was applied for partial destruction of lignocellulosic biomass. The crushed and dried LGS biomass (5 g) was treated with $100 \mathrm{~cm}^{3}$ of weak alkaline solution (mixture of $1 \% \mathrm{Na}_{2} \mathrm{CO}_{3}$ and $1 \% \mathrm{NaCl}$ ) for $2 \mathrm{~h}$ at $23 \pm 0,2{ }^{\circ} \mathrm{C}$ and atmospheric pressure, with constant stirring on a magnetic stirrer (150 rpm). After filtration, multiple rinsing with deionized water and drying $\left(60^{\circ} \mathrm{C}\right)$, the obtained alkaline treated $L$. vulgaris biomass (LVAT) was characterized by physico-chemical methods and spectroscopic FTIR analysis, and then used as a precursor for the synthesis of cationic sorbent.

\section{The first sorbent synthesis process}

In the first synthesis process of cationic sorbent, tertiary TMA was used as the reagent. The prepared LGS biomass, or LVAT precursor $(10 \mathrm{~g})$, were suspended in DMF $\left(60 \mathrm{~cm}^{3}\right)$ at $23 \pm 0.2{ }^{\circ} \mathrm{C}$. After adjusting the $\mathrm{pH}$ to 10.0 using a $\mathrm{NaOH}$ solution $(5 \mathrm{M})$, the mixture was transferred to a glass reactor $\left(250 \mathrm{~cm}^{3}\right)$ and stirred for $30 \mathrm{~min}$ at $80 \pm 0.2^{\circ} \mathrm{C}$. The $\mathrm{ECH}$ reagent $\left(50 \mathrm{~cm}^{3}\right)$ was then added dropwise to the reaction vessel, which led to the synthesis of hydroxycellulose ether at $80 \pm 0.2^{\circ} \mathrm{C}$ for $2 \mathrm{~h}$. Conversion of hydroxycellulose to epoxycellulose ether was achieved in the presence of PIR $\left(20 \mathrm{~cm}^{3}\right)$ as a catalyst, at $80 \pm 0.2^{\circ} \mathrm{C}$ over the next $30 \mathrm{~min}$. The highly reactive epoxidated intermediate was quaternized by the gradual introduction of TMA $\left(50 \mathrm{~cm}^{3}\right)$ into the reaction vessel. Synthesis of cationic sorbent was carried out at a temperature of $80 \pm 0.2{ }^{\circ} \mathrm{C}$ for $4 \mathrm{~h}$. The resulting product was filtered and washed first with $50 \%$ aqueous ethanol at $40{ }^{\circ} \mathrm{C}$, followed by $\mathrm{NaOH}(0.1 \mathrm{M})$ and $\mathrm{HCl}(0.1 \mathrm{M})$ solutions to remove excess chemicals and undesirable by-products. The final product was washed with deionized water at $40{ }^{\circ} \mathrm{C}$ and dried in a vacuum at $40{ }^{\circ} \mathrm{C}$ for $2 \mathrm{~h}$. The synthesized cationic sorbents (LGS-TMA and LVAT-TMA) were used in further experiments.
The second sorbent synthesis process

Another process for the synthesis of cationic sorbent involved the use of quaternary ammonium compound (CHMAC) as a reagent. In this regard, $3 \mathrm{~g}$ of precursor (LVAT) was first treated with alkali $(20 \mathrm{mmol} \mathrm{NaOH} / \mathrm{g}$ biomass) at a temperature of $23 \pm 0.2^{\circ} \mathrm{C}$, to activate the primary and secondary - $\mathrm{OH}$ groups of the glucopyranose unit and to convert the cellulose into more reactive alkali-cellulose with characteristic-ONa groups. After $60 \mathrm{~min}$, the original $65 \mathrm{wt} \%$ aqueous CHMAC solution $(20 \mathrm{mmol} / \mathrm{g}$ biomass) was added dropwise to the reaction mixture, gradually increasing the temperature to about $80^{\circ} \mathrm{C}$. The reaction mixture was further treated at $85 \pm 0.2^{\circ} \mathrm{C}$ for 10 $\mathrm{h}$, with constant stirring (200 rpm). The resulting cationic product (LVAT-CHMAC), after filtration and washing with deionized water, was dried for $12 \mathrm{~h}$ at $60{ }^{\circ} \mathrm{C}$ (to a moisture content $<3 \%$ ) and then subjected to characterization and further sorbent experiments.

The third sorbent synthesis process

In the third synthesis process, the cationic surfactant cetyltrimethylammonium chloride (CTAC) was used as a quaternary ammonium reagent. The LVAT precursor $(1 \mathrm{~g})$ was suspended in $500 \mathrm{~cm}^{3}$ of CTAC aqueous solution of a specified concentration. According to the critical micellar concentration $(C M C)$ of this surfactant $\left(1.28 \mathrm{mmol} \mathrm{dm}^{-3}\right)$, two different concentrations of solution were used: below CMC $(0.9 \times \mathrm{CMC})$ and in excess $(2 \times \mathrm{CMC})$, i.e. 1.15 and $2.56 \mathrm{mmol} \mathrm{dm}^{-3}$ respectively. The suspension was then stirred on a magnetic stirrer $(150 \mathrm{rpm})$ for $8 \mathrm{~h}$ at $23 \pm 0.2{ }^{\circ} \mathrm{C}$. The solid phase was filtered and washed repeatedly with deionized water, until a neutral reaction with $\mathrm{Cl}$-ions (detected with $0.1 \mathrm{M} \mathrm{AgNO}_{3}$ solution). The sample was dried at $80{ }^{\circ} \mathrm{C}$ for $4 \mathrm{~h}$. Prepared sorbents LVAT-CTAC1 (lower concentrations, $0.58 \mathrm{mmol} \mathrm{g}^{-1}$ biomass) and LVAT-CTAC2 (higher concentrations, $1.28 \mathrm{mmol} \mathrm{g}^{-1}$ biomass) were used to test the anion sorption efficiency.

\section{Sorption processes}

The sorption processes were performed on model phosphate and nitrate solutions, in a batch mode, to determine the sorption efficiency of the synthesized cationic products. The working solution $\left(50 \mathrm{~cm}^{3}\right)$ of the test anion species (phosphate or nitrate) of desired concentration $\left(10 \mathrm{mg} \mathrm{dm}^{-3}\right.$ ) was stirred (150 rpm) without the effect of turbulence (vortex effect). The temperature of the solution was maintained constant $\left(25 \pm 0.2^{\circ} \mathrm{C}\right)$ using a water bath with automatic temperature control. The initial $\mathrm{pH}$ of the solution was adjusted to the value of $6.8 \pm$ 0.1 with $\mathrm{HCl}(0.1 \mathrm{M})$ or $\mathrm{NaOH}(0.1 \mathrm{M})$. After checking the zero sample for initial solution concentration, a certain amount of test sorbent (optimally $2.0 \mathrm{~g} \mathrm{dm}^{-3}$ ) was added to the working solution. Aliquot of the solution $\left(30 \mathrm{~cm}^{3}\right)$ was taken after $60 \mathrm{~min}$ and filtered through a regenerated cellulose membrane filter $(0.45 \mu \mathrm{m})$. The filtrate was properly labeled, preserved as necessary by nitric acid (for phosphates) or chloroform (for nitrates), and stored in the refrigerator (at $+4{ }^{\circ} \mathrm{C}$ ) until quantitative analysis by 
the appropriate method.

The concentration of phosphate in solution (expressed as $\mathrm{P}_{-} \mathrm{PO}_{4}$ ) was determined using the ICP-OES method on an ARCOS FHE12 device (Spectro, Germany) [30]. The nitrate concentration in solution (expressed as $\mathrm{N}-\mathrm{NO}_{3}$ ) was determined using the standard $4500-\mathrm{NO}_{3}$ method - procedure B [31], on a UV-VIS spectrophotometer (Cary-100 Conc., Varian) [32].

The content of anions sorbed by the synthesized sorbent (i.e. sorption capacity of sorbent) over a given time interval $(t)$ of the sorption process (as well as in equilibrium) was calculated based on the difference of the initial and final (equilibrium) concentration of the anions in solution, using the expression:

$Q_{t}=\left(C_{0}-C_{t}\right) \cdot V / m$

where: $Q_{t}\left(\mathrm{mg} \mathrm{g}^{-1}\right)$ is amount of sorbed P or $\mathrm{N}$ per gram of sorbent at time $t ; C_{0}$ and $C_{t}\left(\mathrm{mg} \mathrm{dm}^{-3}\right)$ are concentrations of $\mathrm{P}$ or $\mathrm{N}$ in initial solution and solution after time $t$, respectively; $V\left(\mathrm{dm}^{3}\right)$ is the solution volume, and $m(\mathrm{~g})$ is mass of dry sorbent.

\section{Characterization methods}

Characterization of the starting lignocellulosic biomass and synthesized sorbents was performed by typical physico-chemical methods, according to standard AOAC (Association of Official Analytical Chemists) procedures [33]. Physico-chemical analysis included the determination of immediate (moisture, volatile matter and ash), structural (cellulose, hemicellulose, lignin and proteins) and physical properties (density and bulk weight), in accordance with $A O A C$ procedures.

\section{Elemental analysis}

Elemental (CHNS/O) analysis of tested samples was performed using an Elemental Analyzer (Vario EL III CHNS/O Systems, $\mathrm{GmbH}$ ). The procedure was carried out in accordance with the manufacturer's instructions. An accurately measured amount of completely dry sample $( \pm 0.01 \mathrm{mg})$ was burned at high temperature $\left(1200^{\circ} \mathrm{C}\right)$ in an oxygen stream, whereby carbon was converted to $\mathrm{CO}_{2}$, hydrogen to water vapor, sulfur to $\mathrm{SO}_{2}$, and organic nitrogen was reduced to gaseous $\mathrm{N}_{2}$. Elemental analysis directly determined the percentage content of the chemical elements (carbon, hydrogen, nitrogen and sulfur) in the sample structure, while the oxygen content was obtained by subtracting the sum of these values from $100 \%$.

\section{Spectroscopic analysis}

FTIR spectra of LGS biomass and alkaline modified LVAT precursor were obtained using a FTIR spectroscope (BOMEM MB-100; Hartmann \& Braun, Canada). FTIR spectra were recorded in the range of $4000-400 \mathrm{~cm}^{-1}$ at $2 \mathrm{~cm}^{-1}$ resolution, and with 16 scans to eliminate noise. Samples for analysis were prepared by the $\mathrm{KBr}$ technique. The obtained FTIR spectra were analyzed using original Win-Bomem Easy software (Hartmann \& Braun, Canada).

\section{Results and discussion}

Biomass pretreatment and precursor production

The application of an appropriate pretreatment of LGS biomass for partial destruction of lignin, with the requirement to preserve structural and unstable polysaccharides (cellulose and hemicellulose) essential for the subsequent sorbent synthesis process, was one of the main research challenges. Considering the literature data [34] and the goal of pretreatment, as well as the established chemical composition of LGS biomass, alkaline pretreatment was chosen as the most suitable from the numerous methods used in practice. Since strong alkaline reagents can lead to significant loss of important polysaccharides, green liquids are recommended as weak reagents, leading to mild degradation of ligno-cellulosic biomass, with increased delignification selectivity [35]. In order to preserve the important structural constituents of LGS biomass, and primarily because of its ecological significance, a $1 \% \mathrm{Na}_{2} \mathrm{CO}_{3}$ solution was chosen as the optimal reagent for the pretreatment process. The purpose of this study was to determine the effect of the green pretreatment process (using $\mathrm{Na}_{2} \mathrm{CO}_{3}$ ) on the chemical composition and structural changes of lignocellulosic LGS biomass, under normal reaction conditions (room temperature and atmospheric pressure). The comparative results of the physico-chemical analysis of the raw LGS and alkaline treated $L$. vulgaris shell (LVAT) are shown in Table 1. All values are expressed as a percentage (based on dry mass) and represent the mean of three repeated measurements.

Table 1. Physico-chemical properties of raw and alkaline treated $L$. vulgaris shell $\left(1 \% \mathrm{Na}_{2} \mathrm{CO}_{3}\right.$ and $1 \% \mathrm{NaCl}$, for 2 hours, at $150 \mathrm{rpm}$ )

\begin{tabular}{lcccc}
\hline \multicolumn{1}{c}{ Parameter } & Raw LGS & Loss & LVAT & Rinsed LVAT \\
\hline Mass & $5.00 \pm 0.01 \mathrm{~g}$ & $-15.2 \%$ & $4.24 \pm 0.01 \mathrm{~g}$ & $4.22 \pm 0.02 \mathrm{~g}$ \\
Cellulose & $39.58 \pm 0.42 \%$ & $0 \%$ & $47.01 \pm 0.33 \%$ & $47.12 \pm 0.26 \%$ \\
Hemicellulose & $18.22 \pm 0.14 \%$ & $-71.4 \%$ & $6.14 \pm 0.08 \%$ & $6.01 \pm 0.13 \%$ \\
Lignin & $41.90 \pm 0.51 \%$ & $-5.2 \%$ & $46.84 \pm 0.27 \%$ & $46.87 \pm 0.34 \%$ \\
Color of solution & colorless & brown-red & dark yellow & colorless \\
pH of solution & 6.7 (filtrate) & 10.1 (filtrate) & 8.6 (filtrate) & 6.8 (filtrate) \\
\hline
\end{tabular}

The most abundant component in raw LGS biomass is lignin $(\approx 42 \%)$. The high content of holocellulose in the raw material $(\approx 58 \%)$ indicates a considerable representation of $\mathrm{OH}$ groups, as active centers for epoxidation reactions during sorbent synthesis. The protein content is extremely low $(<0.1 \%)$, whereas volatiles were detected since the shell of $L$. vulgaris had already been naturally dried, which was one of the advantages of using this plant material [35]. Also, this plant material is characterized by low ash content $(0.28 \%)$, mainly consisting of bio-accumulated metals during plant growth, such as $\mathrm{Zn}$ (11.5 ppm), Cu (5.5 ppm), Mn (1.1 ppm) and others [17]. The biomass is characterized by a moisture content of $3.8 \%$, a density of $0.46 \mathrm{~g} \mathrm{~cm}^{-3}$ and a bulk weight of 103 $\mathrm{kg} \mathrm{m}^{-3}$. These data are consistent with the characteristics of other plant materials of the genus Lagenaria [36]. 
Comparative analysis of the chemical composition of the various agricultural by-products indicated that LGS biomass is very similar in nature to almond, walnut and peanut shells, taking into account the content of lignin and holocellulose [35]. However, it should be borne in mind that the same plant material, but of different origin (habitat), can have a very different composition, which would certainly affect its modification, different yield and efficiency of the cationic product [37].

As shown by the physico-chemical analysis of the samples before and after pretreatment under normal conditions (Table 1), the procedure efficiency was confirmed by the loss of sample mass, color changes of the solution and change of filtrate $\mathrm{pH}$ value. A change in the mass of raw LGS during alkaline pretreatment from 5.0 $\mathrm{g}$ to $4.24 \mathrm{~g}(15.2 \%)$ indicated a change in chemical composition. Thus, a significant decrease in hemicellulose content (of $71.4 \%$ ) and partly lignin (of $5.2 \%$ ) was registered in the treated LVAT product, which directly affected the enrichment of biomass with cellulose. After rinsing the alkaline treated sample with deionized water, an increase in cellulose content was observed from an initial $39.6 \%$ to a final $47.12 \%$.

These results are in agreement with the literature, where only auto-hydrolysis of rice straw biomass (without alkali) at $120{ }^{\circ} \mathrm{C}$ achieved a total removal of $7.1 \%$ of lignin, while pretreatment with a mild alkaline solution $\left(4 \% \mathrm{Na}_{2} \mathrm{CO}_{3}\right)$ at $120{ }^{\circ} \mathrm{C}$ removed $11.9 \%$ of total lignin [38]. In addition, it is characteristic that during alkaline pretreatment of raw LGS biomass there was an intense coloration of the solution (from colorless to brown-red). During multiple rinsing of treated LVAT biomass with deionized water, the filtrate color changed from dark yellow to a colorless. The characteristic brown-red color of the reaction solution during alkaline pretreatment of biomass was likely due to the released pigments and the resulting degradation products from the plant cell wall (organic resin compounds, pectins, oxidized phenols and some organic acids) [39]. Due to the depolymerization of pectin (polygalacturonic acid polymer) and hemicellulose, constituents such as cinnamic, glucuronic and galacturonic acids were released. On this occasion, $\mathrm{Ca}$ (II) ions, which maintained a stable pectin structure, were also removed [39].

An important index to assess the pretreatment efficacy was also the change in the $\mathrm{pH}$ of the solution (Table 1). The high $\mathrm{pH}$ of the stock solution (about 10.1) during biomass pretreatment leads to the breaking of ester bonds between lignin, hemicellulose and cellulose, as well as secondary reactions of polysaccharides (mainly released hemicellulose, which is considerably sensitive to hydrolysis). Also, substituted uronic and acetyl groups on hemicellulose can be hydrolyzed to form uronic acid and acetic acid, resulting in the formation of more acidic substances [40]. Thus, these organic acids decreased the $\mathrm{pH}$ from 10.1 to 8.6 during alkaline pretreatment (Table 1). To remove undesirable agents (non-renewable alkali salts) and released oligosaccharide or monomer constituents, the biomass was filtered and subsequently rinsed with deionized water to discolorate a dark yellow filtrate, whereby $\mathrm{pH}$ of 6.8 was detected.

The results of physicochemical tests have confirmed that alkaline pretreatment leads to the partial release of individual constituents from the lignocellulose matrix and the removal of their hydrolyzed fragments from the system. However, after the applied pretreatment process, it was found that about $78 \%$ of total polysaccharides was retained in the treated LVAT biomass, which is important for further application of the obtained precursor.

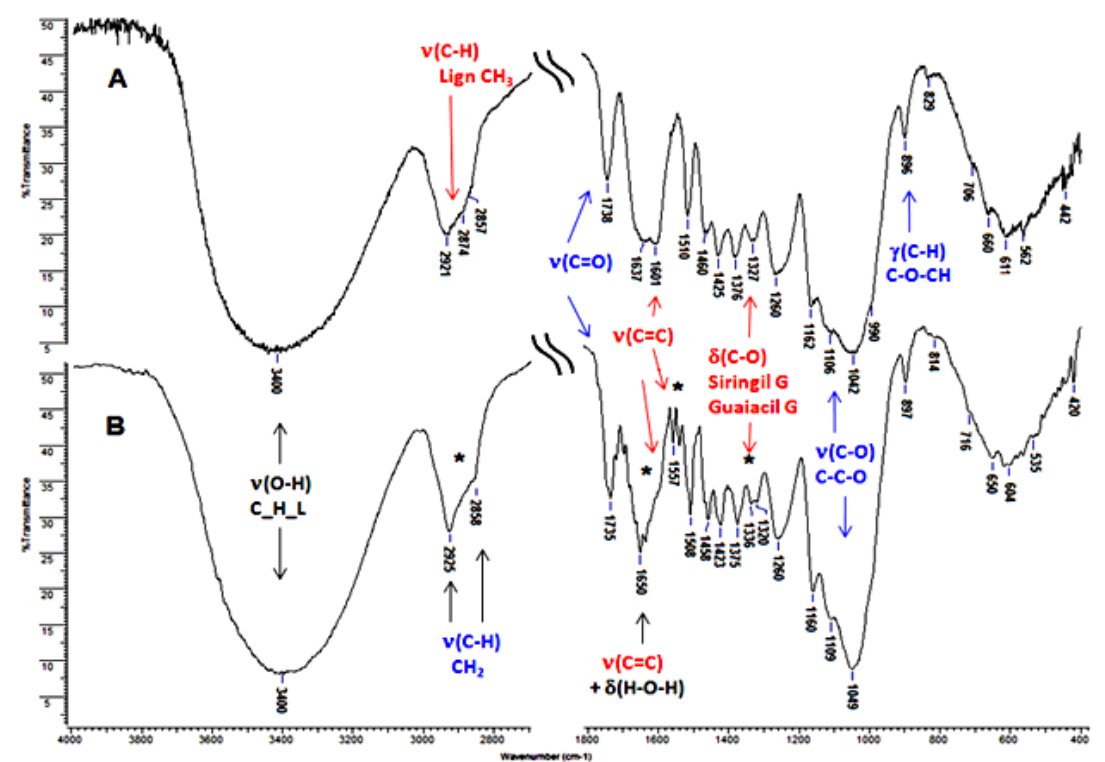

Figure 2. FTIR spectra of raw LGS biomass (A) and LVAT precursor (B); characteristic changes in the spectral region are emphasized by asterisk 
Spectroscopic analysis of biomass and precursor

Given the high degree of mutual correlation of characteristic functional groups and vibrations of chemical bonds, the identified changes in the absorption IR bands of lignocellulosic biomass during pretreatment were closely related to the nature of the analyzed materials and conditions applied [41]. Comparative FTIR spectra of raw LGS biomass and alkaline treated LVAT precursor are shown in Figure 2.

The FTIR spectra of analyzed samples (Figure 2) in the $3800-2700 \mathrm{~cm}^{-1}$ region are typical for ligno-cellulosic biomass. The wide band in the $3600-3000 \mathrm{~cm}^{-1}$ region is characteristic for the valent vibrations of $\mathrm{O}-\mathrm{H}$ groups of different types, as well as the expected electrostatic interactions (intra- and inter-hydrogen bonds) between constituents within the cell wall structure. The bands at $2925 \mathrm{~cm}^{-1}$ and $2858 \mathrm{~cm}^{-1}$ are characteristic for $\mathrm{C}-\mathrm{H}$ stretching vibrations of aliphatic $-\mathrm{CH}_{2}$ and $-\mathrm{CH}$ groups of glucopyranose monomers, which are predominantly in correlation with the presence of holocellulose in the sample. The characteristic band of $\mathrm{C}-\mathrm{H}$ stretching vibration at $2874 \mathrm{~cm}^{-1}$ in the IR spectrum of raw LGS biomass (Figure $2 \mathrm{~A}$ ) is in correlation with the lignin constituent. Therefore, this IR band can be used preliminary to analyze the behavior of lignin during alkaline pretreatment. The decrease in the intensity of this IR band in the LVAT spectrum (Figure 2B), which is not clearly apparent due to overlapping, indicates possible degradation and partial loss of lignin from the sample during alkaline treatment.

The band at $1738 \mathrm{~cm}^{-1}$ was derived from saturated ester $\mathrm{C}=\mathrm{O}$ and was correlated with the presence of hemicellulose in the sample. The band intensity reduction in the spectrum of LVAT sample indicated that hydrolysis of glycosidic C-O-C bonds, depolymerization of released hemicellulose and its partial removal from biomass resulted in hydrolysis during alkaline pretreatment. In the spectral region $1700-1560 \mathrm{~cm}^{-1}$ there was a complex IR band (Figure 2A), with centroids at about $1640 \mathrm{~cm}^{-1}$ and $1600 \mathrm{~cm}^{-1}$. This broad band indicated the overlap of O-H vibrations of the water molecule (cellulose crystallohydrate), as well as the presence of phenolic and carboxyl groups with skeletal vibrations of lignin rings. The appearance of the band in this region is different after alkaline pretreatment of the biomass (Figure 2B). The more pronounced centroid was shifted to $1650 \mathrm{~cm}^{-1}$, while the intensity of the band at about $1600 \mathrm{~cm}^{-1}$ was considerably reduced, which is characteristic of lignin-conjugated rings. The band at $1510 \mathrm{~cm}^{-1}$ was derived from skeletal vibration of the lignin aromatic ring and it was of approximately the same intensity in both analyzed biomass samples. However, LVAT precursor was characterized by the appearance of doublet at about $1557 \mathrm{~cm}^{-1}$, indicating different types of aromatic $\mathrm{C}=\mathrm{C}$ skeletal vibrations of lignin fragments. This was supported by the possibility of the presence of lignin fragments of a different nature in the analyzed samples [42].

Namely, lignin subunits that are incorporated into the polymer can be identified by the characteristic structure of the aromatic rings, from which the most important are guaiacyl, syringyl and p-hydroxyphenyl. Molecules consist of methoxyl, acetyl and formyl groups. This difference in composition has a major impact on delignification, as well as on biomass destruction. Typically, guaiacyl units are more often networked at the C-5 position of the aromatic ring, so these cross-linked $\mathrm{C}-\mathrm{C}$ bonds (formed during lignification) make it difficult to delignify biomass since they cannot be hydrolyzed either by acid or base [28]. Contrary to that, the C-5 position in syringyl units is substituted, and therefore cannot participate in the reactions of further substitution. Thus, the intense band at about $1650 \mathrm{~cm}^{-1}$ in the IR spectrum of LVAT precursoe (Figure 2B) corresponds to $\mathrm{C}=\mathrm{C}$ valent vibrations in the monomeric side chain within the lignin polymer, while the low intensity band at $1327 \mathrm{~cm}^{-1}$ corresponds to the vibration of the condensed syringyl G-ring, i.e. coniferyl alcohol substituted at C-5 position. Spectral analysis confirms an $\mathrm{C}=\mathrm{C}$ side chains group increase (the band moving to $1650 \mathrm{~cm}^{-1}$ with intensity increasing), while reducing the amount of condensed structures (decreasing the intensity of the band to about $1600 \mathrm{~cm}^{-1}$ and doubling the band to about $1327 \mathrm{~cm}^{-1}$ ), which are characteristic of polymers formed by mixing coniferyl alcohol with ferulic acid (hydroxycinnamic acid).

The IR band doubling (from $1327 \mathrm{~cm}^{-1}$ to 1336 and $1320 \mathrm{~cm}^{-1}$ ), that is less pronounced in the untreated LGS biomass, indicates lignin polymer of pure coniferyl alcohol presence in the LVAT precursor. A slight intensity increase of the band at $1260 \mathrm{~cm}^{-1}$ in the IR spectrum can be explained by an increase in the number of $\mathrm{C}-\mathrm{O}$ bonds due to the presence of ferulic acid in the lignin polymer. Different active bands relations in the spectrum of LVAT precursor, to about $1423 \mathrm{~cm}^{-1}, 1260 \mathrm{~cm}^{-1}, 1050 \mathrm{~cm}^{-1}$ and the transit at $956 \mathrm{~cm}^{-1}$, compared to the complex band at about $1630 \mathrm{~cm}^{-1}$ in the spectrum of LGS biomass, indicate that lignin polymers differ by ferulic acid content and have clear structural differences. This fact also confirms the effect of alkaline pretreatment on the structural changes of the lignin biomass constituent.

In the IR spectrum of LVAT precursor (Figure 2B) the doubling of the band at $1460 \mathrm{~cm}^{-1}$ was detected, which originates from $\mathrm{C}-\mathrm{H}$ deformation vibrations (in the plane) of all the present biomass constituents. This fact points to the effect of alkaline pretreatment in terms of inter and intra-molecular matrix hydrogen bonds break, and thus, a better separation of biomass constituents and their clearer insight into the spectrum. IR bands at $1375 \mathrm{~cm}^{-1}$ (C-H vibrations) and $1327 \mathrm{~cm}^{-1}$ (C-O vibrations) may be correlated with the xyloglucan presence in the cell wall (the major hemicellulose polysaccharide, an enzyme that catalyzes $\beta$-1,4-bonds). However, it should be noted that these bands, together with a deformation vibration band of $\mathrm{OH}$ group (in plane) at $1423 \mathrm{~cm}^{-1}$ and a wide band of the vibration of the cellulose ester group at $1260 \mathrm{~cm}^{-1}$, are correlated with the crystalline cellulose structure [43]. Thus, the apparently small changes in band intensity indicate a 
proportional change in the fraction of the crystalline to amorphous form of certain cellulose areas in the treated sample, which favors more efficient sorbent synthesis based on this precursor.

The broad band in the $1100-900 \mathrm{~cm}^{-1}$ range, which is characteristic of most polysaccharides, shows a significant overlap of $\mathrm{C}-\mathrm{OH}$ and $\mathrm{C}-\mathrm{C}-\mathrm{O}$ vibrations in the spectrum of LGS biomass (with a inflection at $990 \mathrm{~cm}^{-1}$ ). Its finer structure observed in the LVAT spectrum, where the maximum of the intensive band is moved from $1040 \mathrm{~cm}-1$ to $1050 \mathrm{~cm}^{-1}$. The band at $830 \mathrm{~cm}^{-1}$ in the IR spectrum of LGS biomass (Figure 2A) is characteristic of anomeric a-glucosidic bonds of hemicellulose that occurs only in the cell wall of LGS biomass. In the spectrum of LVAT precursor, the intensity of this band is greatly reduced due to hemicellulose destruction, resulting in the appearance of the band at $815 \mathrm{~cm}^{-1}$, that derives from deformation $\mathrm{C}=\mathrm{C}$ vibrations of lignin fragments. The deformation $\mathrm{C}-\mathrm{H}$ vibrations characteristic of the anomeric $\beta$-glycosidic (C-O-CH) bonds of cellulose at $896 \mathrm{~cm}^{-1}$ and $990 \mathrm{~cm}^{-1}$ remain unchanged during pretreatment which suggest the structural stability of the cellulose chain to adequately applied reaction conditions.

Based on the IR spectral analysis of the tested samples, it can be concluded that alkaline pretreatment of lignocellulosic gourd biomass (using a carbonate solution) results in: a) destruction of the lignin matrix structure (hydrolysis of ester bonds of molecules such as ferulic and acetic acid); b) disturbance of the interaction between lignocellulosic components (breaking of interand intra-hydrogen bonds); c) release of hemicellulose molecules due to hydrolysis of ester bonds between hemicelluloses xylan and cellulose; d) degradation and dissolution of more susceptible hemicelluloses, due to the low degree of polymerization, branched structure and amorphous nature (removal of hemicelluloses xylan is significantly higher than glucan crystalline cellulose); e) subsequent dissolution and removal of ash and mineral matter, as well as the resulting by-products (phenolic and acid type) that would have a negative effect on the subsequent modification of biomass to the target sorbent. These conclusions are in accordance with the other authors discussion about the alkaline pretreatment conducted on lignocellulosic biomasses of similar constitution $[28,42,44,45]$.

\section{Characterization of synthesized cationic sorbents}

Synthesis of cationic sorbents based on lignocellulosic gourd shell (synthesis precursor) was performed in three ways, according to the literature procedures provided for modification of lignocellulosic biomass $[13,16]$. A different N-reagent (TMA as a tertiary amino compound and CHMAC and CTAC as quaternary ammonium compounds) was used in the cation modification of the starting LGS biomass, as well as LVAT precursor, to determine the effects of reagent structure and hydrophobicity on the synthesis outcome, and primarily on the sorption properties of the resulting sorbent.
Characterization of sorbents obtained by various synthesis methods was conducted to confirm the introduction of quaternary cationic groups into the structure of LGS biomass, or LVAT precursor. The elemental (CHNS/O) analysis and reaction efficiency (RE) of the synthesized sorbents based on lignocellulosic gourd shell, compared to some cationized agricultural by-products tested for the removal of anionic pollutants [9], as well as commercial ion-exchange resin, are shown in Table 2. Other characteristic parameters, such as: degree of substitution (DS), amount of added cationic groups (Nadd), and product yield were determined as a function of nitrogen content $(\mathrm{N})$.

Table 2. Elemental (CHNS/O) analysis and reaction efficiency of the synthesized sorbents, some cationic biomasses and commercial ion-exchange resin

\begin{tabular}{|c|c|c|c|c|c|c|c|c|}
\hline \multirow{2}{*}{ Samples } & \multicolumn{4}{|c|}{ Elements (\%) } & \multirow{2}{*}{$\begin{array}{c}\text { Nadd } \\
\left(\mathrm{mmol} \mathrm{N} \mathrm{g}^{-1}\right)\end{array}$} & \multirow{2}{*}{$\begin{array}{l}\mathrm{RE} \\
\text { (\%) }\end{array}$} & \multirow{2}{*}{ DS } & \multirow{2}{*}{$\begin{array}{l}\text { Yield } \\
(\%)\end{array}$} \\
\hline & C & $\mathrm{H}$ & 0 & $\mathrm{~N}$ & & & & \\
\hline LGS biomass & 45.46 & 5.98 & 48.55 & 0.01 & - & - & - & - \\
\hline LVAT precursor & 45.51 & 5.84 & 48.65 & 0.01 & - & - & - & 84.4 \\
\hline LGS-TMA sorbent & 46.81 & 6.53 & 45.08 & 1.58 & 1.12 & 4.39 & 0.20 & 91.3 \\
\hline LVAT-TMA sorbent & 47.67 & 6.34 & 44.25 & 1.74 & 1.24 & 4.86 & 0.22 & 94.6 \\
\hline LVAT-CHMAC sorbent & 47.22 & 6.12 & 44.71 & 1.95 & 1.39 & 6.95 & 0.31 & 98.8 \\
\hline LVAT-CTAC1 sorbent & 52.33 & 6.67 & 40.20 & 0.79 & 0.56 & 97.39 & 0.11 & 97.4 \\
\hline LVAT-CTAC2 sorbent & 60.09 & 6.95 & 31.52 & 1.43 & 1.01 & 78.91 & 0.25 & 97.9 \\
\hline walnut shell & & & & 0.76 & 0.34 & 1.70 & & 93.4 \\
\hline peanut shell & & & & 1.25 & 0.65 & 3.27 & & 98.1 \\
\hline almond shell & & & & 2.22 & 1.43 & 4.10 & & 95.5 \\
\hline rice husk & & & & 2.40 & 1.45 & 7.26 & & 88.2 \\
\hline corn kernels & & & & 2.78 & 1.38 & 6.90 & & 70.8 \\
\hline soybean shell & & & & 2.61 & 0.72 & 3.61 & & 65.0 \\
\hline${ }^{*}$ QA52 resin & & & & - & 1.07 & - & & - \\
\hline
\end{tabular}

Elemental analysis (CHNS/O) was applied to evaluate the added functional groups in the synthesized sorbents during the biomass modification process. The presence of sulfur was not identified in the samples tested. Based on the results of elemental analysis (Table 9), it was found that the $\mathrm{CHO}$ content in LGS biomass $(\mathrm{H} / \mathrm{C}$ ratio 0.13 ) is very similar to the results of other studies (C 42-59\%, H 3-7\% and O 32-50\%) [9,17]. The content of these elements in LGS biomass did not change significantly after the alkaline pretreatment process. Significant changes in nitrogen content were observed in all samples of the synthesized sorbents, which confirms the efficiency of LVAT precursor cationisation.

Sorbents based on the $\mathrm{N}$-reagents.

The synthesis of sorbents by TMA reagent shows that pretreatment has a significant contribution to the introduction of cationic $\mathrm{N}$-groups into the biomass structure. Thus, after ECH-TMA modification of raw LGS biomass, an increase of $\mathrm{N}$ content of $1.74 \%$ in the final product was observed. It was calculated that $17.36 \mathrm{mg} \mathrm{N} \mathrm{g}^{-1}$ in the form of the $-\mathrm{N}^{+} \mathrm{R}_{3}$ cation group was bound on the biomass surface, indicating the theoretical ion-exchange capacity of $1.24 \mathrm{mEq} \mathrm{g}^{-1}$ for LVAT-TMA sorbent. Similar observations were noticed in the case of LVAT-CHMAC sorbent synthesis, but the quaternary ammonium CHMAC reagent contributes to a higher ion exchange 
capacity of the sorbent $\left(1.39 \mathrm{mEq} \mathrm{g}^{-1}\right)$. This result suggests that treatment with CHMAC reagent is significantly more effective compared to TMA for the synthesis of cationic sorbents [46].

However, given the results of reaction efficiency (RE $4.39-6.95 \%$ ) and degree of substitution (DS $0.20-0.31$ ), it can be said that the reaction between LGS biomass and amino/ammonium reagent was not particularly effective. This can be very important in semi-industrial (scale-up) process, because it is one of the factors that determine the product cost [9]. Given that the synthesis of sorbents was carried out with amino/ammonium reagents in excess $\left(25.5 / 20.0 \mathrm{mmol} \mathrm{g}^{-1}\right.$ versus $3.4 \mathrm{mmol} \mathrm{g}^{-1}$ glucopyranose precursor units), it can be assumed that the number of reagents used is not a limiting factor in the synthesis outcome. The excess reagent represents the theoretically required ratio for the maximum binding of 3 reagent molecules to one primary and two secondary $-\mathrm{OH}$ groups of glucopyranose units and the same number of reagent molecules to the phenolic $-\mathrm{OH}$ groups of lignin monomers. On the other hand, the calculated DS values give the impression that substitution occurs on every fifth unit of glucopyranose in the cellulose chain in the case of TMA reagents, or every third unit in the case of CHMAC reagents. If one assumes that the reaction efficiency is a property of biomass and not of the amount of reagent, the problem can be overcome by simply reducing the initial concentration of the cationic reagent [46].

These assumptions can be explained by the fact that the availability of reactive sites of lignocellulosic biomass is most likely the limiting factor of the reaction efficiency. In this regard, reaction barriers can be represented by the biomass density (as a function of material composition) and the amount of lignin in the material. Bulk density can be the result of lignification degree in this case, since the bulk density of the biomass shows an inverse linear correspondence with the amount of added cationic groups [9]. Therefore, it is believed that there may be diffusion limitations on the reaction between the cationic reagent and the reactive cellulose as a result of the bulk density $\left(0.46 \mathrm{~g} \mathrm{~cm}^{-3}\right.$ in the case of LGS biomass). Similarly, small values of reaction efficiencies were found for other quaternized agricultural by-products tested for phosphate removal (Table 2), which varied from $1.70 \%$ for the walnut shell of higher density $\left(0.64 \mathrm{~g} \mathrm{~cm}^{-3}\right)$ to $7,26 \%$ for the rice husk of low-density $\left(0.27 \mathrm{~g} \mathrm{~cm}^{-3}\right)$. For the same reason, highly lignified LGS biomass $(41.90 \%$ ) does not react so well with TMA reagent (or CHMAC) because of its limited access to cellulose, which is the primary component of the cell wall. Also, many authors have confirmed that delignification of ligno-cellulosic materials can increase the efficiency of the quaternization reaction $[8,34,47]$.

The noticeable variation in $\mathrm{CHO}$ content and yield values lower than $100 \%$ in all observed cases may be due to the binding of epoxy groups and $\mathrm{N}$-reagents to the surface of the biomass on the one hand, as well as the destruction of the biomass (i.e. hemicellulose extraction) on the other, as confirmed by spectroscopic FTIR analysis. Specifically, the lower product yield is based on a more significant weight loss of the product due to alkaline treatment $(\mathrm{NaOH}, \mathrm{pH}>10)$ compared to the mass contribution from the inclusion of additional cationic $-\mathrm{N}^{+} \mathrm{R}_{3}$ groups. A similar trend of lower yield has been observed in other hemicellulose-rich biomasses [9].

In general, the results of elemental analysis suggest that a significant amount of cationic tertiary or quaternary reagents are involved in the structure of cellulose chains during synthesis, leading to an increase in the nitrogen content of the synthesized sorbents. On the other hand, these results validate the superiority of LGS biomass, or LVAT precursors, for cationic modification compared to numerous agricultural by-products, as well as commercial anion exchanger resins (e.g. QA52 - quaternary ammonium cellulose) tested for anionic species removal (primarily phosphate and nitrate) from aqueous solutions [48].

\section{Surfactant-based sorbents}

Unlike the sorbents analyzed previously, elemental analysis of LVAT-CTAC1 and LVAT-CTAC2 samples (Table 2), obtained by modification of LVAT precursor by a cationic CTAC surfactant of different concentrations, indicated a lower $\mathrm{N}$ content in the products $(0.79 \%$ and $1.43 \%$, respectively). The increase in $\mathrm{N}$ content was proportional to the concentrations of the solutions used. Thus, nearly twice the $\mathrm{N}$ content was registered with LVAT-CTAC2 sample as a result of the use of CTAC reagents solution of higher concentration (> CMC surfactants). This fact points to a possible mechanism of bilayer surfactant aggregation at the biomass surface [49]. Based on the number of cationic groups added to the biomass after modification, the theoretical ion-exchange capacity of $1.01 \mathrm{mmol} \mathrm{N} \mathrm{g}{ }^{-1}$ for LVAT-CTAC2 sorbent was calculated. The high values of reaction efficiency (RE 78.91-97.39\%) and product yield (97.4-97.9\%) indicate maximum utilization of the reagent amount. However, the small degree of substitution and the predicted two-layer mechanism suggest that the obtained data may not be relevant for evaluating the sorption efficiency of anionic species from solution [50]. This can be explained by the fact that at least half of the total amount of bound surfactants are engaged in the interaction with active biomass centers, while the rest are available for the sorption process of anionic contaminants (Figure 3 ). Thus, LVAT-CTAC2 should be expected to have half the theoretically calculated capacity.
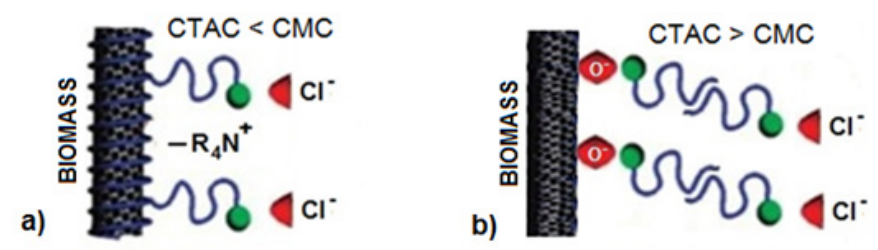

Figure 3. Mechanism of formation of monolayer (a) and bilayer (b) complex aggregates of CTAC surfactants on the surface of ligno-cellulosic biomass [50] 
Efficiency of cationic sorbents

The efficiency of synthesized cationic sorbents was evaluated using the sorption capacity for the anion species tested (phosphates and nitrates). In this regard, a series of experiments were performed to remove phosphate and nitrate from a solution of the same initial concentrations $\left(10 \mathrm{mg} \mathrm{dm}^{-3}\right)$ with a sorbent dose of $2 \mathrm{~g} \mathrm{dm}^{-3}$ in the batch system. These initial anion concentrations were selected according to the effluent quality standards in eutrophication sensitive regions (Council Directive 91/271/EEC). Reaction conditions of the sorption process which proved to be optimal for these purposes according to the literature data (stirring rate $150 \mathrm{rpm}$, contact time $60 \mathrm{~min}$, temperature $25^{\circ} \mathrm{C}, \mathrm{pH}$ 6.8) were selected for comparison [13,51]. Comparative results of testing the efficacy of synthesized cationic sorbents, relative to the starting LGS biomass and LVAT precursor, are presented in Table 3.

Table 3. Sorption efficiency of phosphate and nitrate using different cationic sorbents based on modified gourd shell (equilibrium sorption capacity $Q e$ represents the mean of three consecutive determinations)

\begin{tabular}{lcccc}
\hline \multirow{2}{*}{ Sorbents } & \multicolumn{2}{c}{ Phosphate $\left(10 \mathrm{mg} \mathrm{P} \mathrm{dm}^{-3}\right)$} & \multicolumn{2}{c}{ Nitrate $\left(10 \mathrm{mg} \mathrm{N} \mathrm{dm}^{-3}\right)$} \\
& $Q_{e}\left(\mathrm{mg} \mathrm{g}^{-1}\right)$ & $\%$ & $Q_{e}\left(\mathrm{mg} \mathrm{g}^{-1}\right)$ & $\%$ \\
\hline LGS biomass & $0.04 \pm 0.02$ & 0.8 & $0.03 \pm 0.01$ & 0.6 \\
LVAT precursor & $0.05 \pm 0.03$ & 1.0 & $0.04 \pm 0.02$ & 0.8 \\
LGS-TMA sorbent & $3.27 \pm 0.11$ & 65.4 & $2.77 \pm 0.06$ & 55.4 \\
LVAT-TMA sorbent & $3.94 \pm 0.09$ & 78.8 & $3.43 \pm 0.14$ & 68.6 \\
LVAT-CHMAC sorbent & $4.41 \pm 0.13$ & 88.2 & $3.95 \pm 0.10$ & 79.0 \\
LVAT-CTAC1 sorbent & $2.03 \pm 0.08$ & 40.6 & $1.11 \pm 0.12$ & 22.2 \\
LVAT-CTAC2 sorbent & $1.95 \pm 0.07$ & 39.2 & $1.08 \pm 0.06$ & 21.6 \\
\hline
\end{tabular}

The results of testing the efficiency of cationic sorbents synthesized by different methods, during the process of anions sorption from aqueous solutions of the same initial concentration, under the same reaction conditions, confirmed the success of chemical modification of the starting biomass. Comparing the obtained results, it was found that raw LGS biomass did not show sorption properties for the studied anions $(<1 \%)$. Also, alkaline pretreatment of biomass had no effect on the removal of the tested anion species from the solution by LVAT precursor. However, it is evident that the preparation of LVAT precursor had a significant contribution to increasing the equilibrium sorption capacity of sorbents. Thus, the increased efficiency of phosphate sorption by $13.4 \%$ and nitrate by $13.2 \%$ was observed in LVAT-TMA sorbent application in comparison with LGS-TMA sorbent application. The highest efficiency of anion removal from solution (about $88 \%$ of phosphate and $79 \%$ of nitrate) was demonstrated by LVAT-CHMAC sorbent. Better reaction efficiency and higher degree of substitution of quaternary CHMAC reagent (Table 2) probably contributed to the creation of a larger number of active sites $\left(-N^{+} R_{3}\right)$ on LVAT precursor in relation to the multistage synthesis with the tertiary TMA reagent. A structural model of LVAT-CHMAC sorbent after the sorption of the dominant phosphate $\left(\mathrm{H}_{2} \mathrm{PO}_{4^{-}}\right.$and $\left.\mathrm{HPO}_{4}{ }^{2-}\right)$ and nitrate $\left(\mathrm{NO}_{3}{ }^{-}\right)$anions from the solution is proposed in Figure 4.

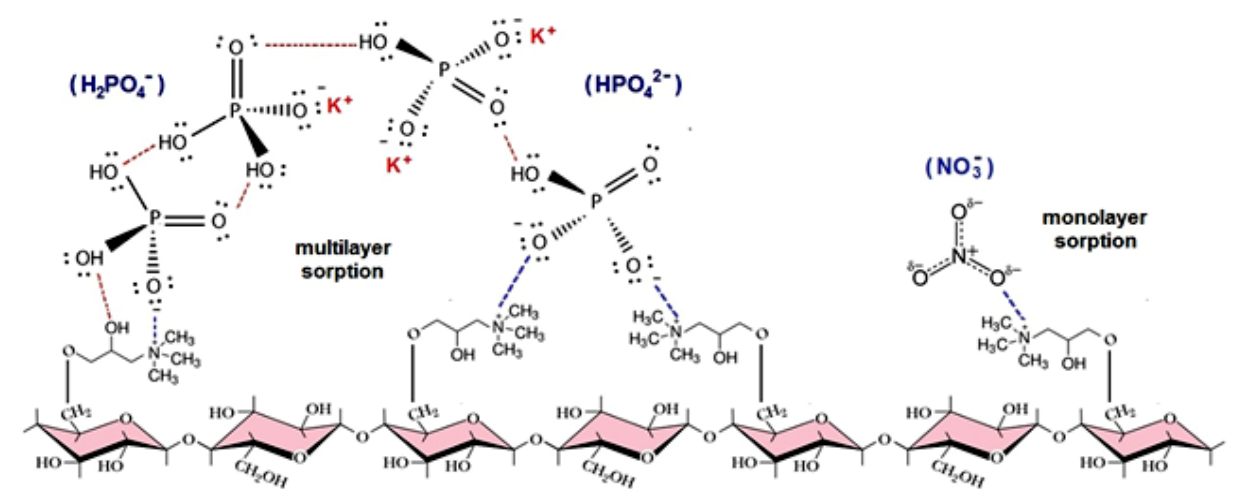

Figure 4. Structural model of the sorbent after sorption of phosphate and nitrate anions [52]

The sorbents obtained by modifying the biomass with CTAC surfactant showed a significantly lower degree of anion sorption (about $40 \%$ for phosphate and $22 \%$ for nitrate) compared to the other tested sorbents (Table 3). As expected, almost identical equilibrium sorption capacity was registered in both observed cases, independent of the surfactant concentration applied (CTAC1 below CMC and CTAC2 above CMC). This may be understandable when considering the model of bilayer complex surfactant aggregates on the biomass surface (Figure 5). The formation of bilayer complex aggregates increases the number of cationic added groups, but not the number of active centers available to interact with the anions present in solution [53]. The lower efficiency of anion sorption by LVAT-CTAC sorbents can be explained by the lower amount of bound surfactant molecules and their mechanism of attachment to the biomass surface, as well as by the influence of the CTAC steric factor relative to CHMAC or TMA reagent [54]. The rheological properties of the solution also contribute to the lower sorption efficiency, since the increase 
in the surfactant concentration leads to an increase in the viscosity of the solution, which directly affects the impeded diffusion of the anion through the solution during sorption and, consequently, the lower degree of anion removal [55]. A similar model of lignocellulosic biomass modified by cationic surfactants, as well as the mechanism of anions removal (phosphate, nitrate, sulfate, chromate) or anionic dyes from contaminated aqueous solutions, have been pointed out by other authors [13,53].

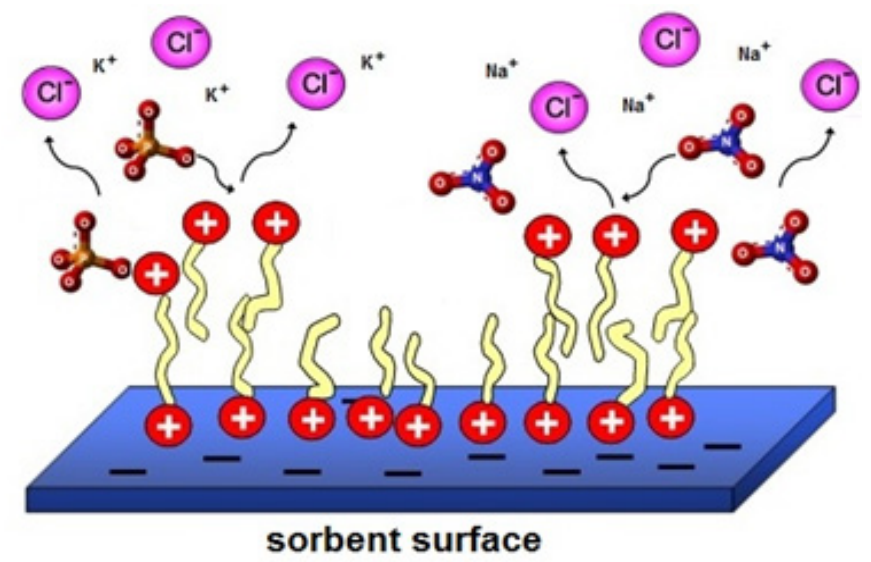

Figure 5. Model of anionic species sorption from aqueous solution on LVAT biomass modified by CTAC surfactant [50]

\section{Conclusion}

This study confirmed that different cationic sorbents can be prepared from a cheap and readily available plant material, $L$. vulgaris fruit, capable of removing a wider range of anionic pollutants from water. The original cationic sorbents based on the lignocellulosic gourd shell with the property of efficient sorption of anions from aqueous solutions, especially phosphate and nitrate, were developed by various biomass treatment methods and the use of three synthesis procedures in order to solve the problem of eutrophication. On the basis of raw LGS biomass and LVAT precursor, obtained by alkaline pretreatment of the lignocellulosic biomass with a green carbonate solution (mixture of $1 \% \mathrm{Na}_{2} \mathrm{CO}_{3}$ and $1 \% \mathrm{NaCl}$ ), three types of the cationic sorbents (LGS-TMA, LVATTMA and LVAT-CHMAC) with ion-exchange property were developed and characterized. In the second case, two types of sorbents (LVAT-CTAC1 and LVAT-CTAC2), obtained by grafting a cationic surfactant onto a lignocellulosic skeleton of biomass under optimal conditions, can be used to remove anionic pollutants from non-polar or mixed effluents, given the more pronounced degree of surface hydrophobicity. The efficiency of the synthesized cationic sorbents compared to the unmodified LGS biomass was evaluated using the sorption capacity for the tested anionic species (phosphates and nitrates) in the batch system, under the same conditions and initial concentrations. The raw LGS biomass as well as the LVAT precursor did not show sorption properties for the studied anions (<1\%). The LVAT-CHMAC sorbent showed more efficient removal of anions from the solution (88\% phosphate and $79 \%$ nitrate) compared to the LVAT-CTAC sorbent (46\% phosphate and $22 \%$ nitrate).

\section{Acknowledgement}

This study was financed by the Serbian Ministry of Education, Science and Technological Development through the project TR 34012.

\section{References}

[1] Everglades hub., Phosphorous removal technologies, 2013. Available at http://www.evergladeshub. com/ okeechobee/P.htm. (Accessed in November 2019).

[2] P.F. Strom, Technologies to remove phosphorous from wastewater, 2006. Available at http://www.water.rutgers. edu/Projects/trading/p-trt-lit-rev-2a.pdf. (Accessed in November 2019).

[3] K.S. Haugen, M.J. Semmens, P.J. Novak, A novel insitu technology for the treatment of nitrate contaminated groundwater, Water Research, 36 (2002) 3497-3506.

[4] A.O. Tanyi, Comparison of chemical and biological phosphorous removal in wastewater - a modeling approach, 2010. Available at http://www.chemeng.Ith.se/ exjobb/E308.pdf. (Accessed in November 2019).

[5] S. Samatya, N. Kabay, U. Yuksel, M. Arda, M. Yuksel, Removal of nitrate from aqueous solution by nitrate selective ion exchange resins, Reactive and Functional Polymers, 6 (2006) 1206-1214.

[6] X. Xu, B-Y. Gao, Q-Y. Yue, Q-Q. Zhong, Preparation of agricultural by-product-based anion exchanger and its utilization for nitrate and phosphate removal, Bioresource Technology, 101(22) (2010) 8558-8564.

[7] D.Z. MarkovićNikolić, A.Lj. Bojić, D.V. Bojić, M.D. Cakić, D.J. Cvetković, G.S. Nikolić, The biosorption potential of modified bottle gourd shell for phosphate: equilibrium, kinetic and thermodynamic studies, Chemical Industry \& Chemical Engineering Quarterly 24(4) (2018) 319-332.

[8] U.S. Orlando, A.U. Baes, W. Nishijima, M. Okada, A new procedure to produce lignocellulosic anion exchangers from agricultural waste materials, Bioresource Technology, 83 (2002) 195-198.

[9] L.H. Wartelle, W.E. Marshall, Quaternized agricultural by-products as anion exchange resins, Journal of Environmental Management, 78(2) (2006) 157-162.

[10] X. Xu, B. Gao, Q. Yue, X. Zhan, Preparation, characterization of wheat residue-based anion exchangers and its utilization for the phosphate removal from aqueous solution, Carbohydrate Polymers, 82(4) (2010) 1212-1218.

[11] S. Alila, S. Boufi, M.N. Belgacem, D. Beneventi, Adsorption of a cationic surfactant onto cellulosic fibers: Surface charge effects, Langmuir, 21 (2005) 8106-8113.

[12] L. Wang, J. Zhang, R. Zhao, C. Li, Y. Li, C. Zhang, Adsorption of basic dyes on activated carbon prepared from Polygonum orientale Linn: Equilibrium, kinetic and thermodynamic studies, Desalination, 254 (2010) 68-74.

[13] T.A.H. Nguyen, H.H. Ngo, W. Guo, T.V. Nguyen, Phosphorous removal from aqueous solutions by agricultural by-products: A critical review, Journal of Water Sustainability, 2(3) (2012) 193-207.

[14] A. Keränen, T. Leiviskä, B-Y. Gao, O. Hormi, J. Tanskanen, 
Preparation of novel anion exchangers from pine sawdust and bark, spruce bark, birch bark and peat for the removal of nitrate, Chemical Engineering Science, 98 (2013) 5968.

[15] T.P. Delforno, A.G.L. Moura, D.Y. Okada, M.B.A. Varesche, Effect of biomass adaptation to the degradation of anionic surfactants in laundry wastewater using EGSB reactors, Bioresource Technology, 154 (2014) 114-121.

[16] A. Kaboorani, B. Riedl, Surface modification of cellulose nanocrystals (CNC) by a cationic surfactant, Industrial Crops and Products, 65 (2015) 45-55

[17] D.L. Mitic-Stojanovic, A. Zarubica, M. Purenovic, D. Bojic, T. Andjelkovic, A. Bojic, Biosorptive removal of $\mathrm{Pb}^{2+}, \mathrm{Cd}^{2+}$ and $\mathrm{Zn}^{2+}$ ions from water by Lagenaria vulgaris shell, Water SA, 37(3) (2011) 303-312.

[18] R. Ljupković, J. Mitrović, M. Radović, M. Kostić, D. Bojić, D-L. Mitić-Stojanović, A. Bojić, Removal Cu(II) ions from water using sulphuric acid treated Lagenaria vulgaris shell (Cucurbitaceae), BiologicaNyssana, 2(2) (2011) 1-5.

[19] M. Stanković, N. Krstić, I. Slipper, J. Mitrović, M. Radović, D. Bojić, A. Bojić, Chemically modified Lagenaria vulgaris as a biosorbent for the removal of $\mathrm{Cu}(\mathrm{II})$ from water, Australian Journal of Chemistry, 66 (2013) 227-236.

[20] M. Kostić, M. Radović, J. Mitrović, M. Antonijević, D. Bojić, M. Petrović, A. Bojić, Using xanthated Lagenaria vulgaris shell biosorbent for removal of $\mathrm{Pb}(\mathrm{II})$ ions from wastewater, Journal of the Iranian Chemical Society, 11(2) (2014) 565578.

[21] D. Bojić, G. Nikolić, J. Mitrović, M. Radović, M. Petrović, D. Marković, A. Bojić, Kinetic, equilibrium and thermodynamic studies of $\mathrm{Ni}(\mathrm{II})$ ions sorption on sulfuric acid treated Lagenaria vulgaris shell, Chemical Industry and Chemical Engineering Quarterly, 22(3) (2016) 235-247.

[22] D. Bojić, M. Ranđelović, A. Zarubica, J. Mitrović, M. Radović, M. Purenović, A. Bojić, Comparison of new biosorbents based on chemically modified Lagenaria vulgaris shell, Desalination and Water Treatment, 51(3436) (2013) 6871-6881

[23] D.Z. Marković, A. Bojić, D. Bojić, G. Nikolić, Postupak uklanjanja herbicida iz prirodnih i otpadnih voda aktivnim ugljem na bazi kore Lagenaria vulgaris, Tehničko rešenje, Ev. br. 06-1038/1, Tehnološki fakultet, Leskovac, 2016.

[24] D. Bojić, Razvoj i primena eko-sorbenata na bazi modifikovane ligno-celulozne biomase, Doktorska disertacija, Univerzitet u Nišu, Tehnološki fakultet, Leskovac, 2016.

[25] A.S. Rahman, Bottle gourd (Lagenariasiceraria): A vegetable for good health, Natural Product Radiance, 2 (2003) 249-250.

[26] R.P. Prajapati, M. Kalariya, S.K. Parmar, N.R. Sheth, Phytochemical and pharmacological review of Lagenariasicereria, Journal of Ayurveda and Integrative Medicine, 1(4) (2010) 266-272.

[27] R. Mohan, R. Birari, A. Karmase, S. Jagtap, K.K. Bhutani, Antioxidant activity of a new phenolic glycoside from Lagenaria siceraria Stand. fruits, Food Chemistry, 132 (2012) 244-251.

[28] A. Brandt, J. Gräsvik, J. Hallett, T. Welton, Deconstruction of lignocellulosic biomass with ionic liquids, Green Chemistry, 15 (2013) 550-583.

[29] G.O. Ribeiro, R.J. Gruninger, A. Badhan, T.A. McAllister, Mining the rumen for fibrolytic feed enzymes, Animal Frontiers, 6(2) (2016) 20-26.

[30] D. Marković, G. Petković, Zaštita životne sredine, I deo: Ispitivanje i prečišćavanje voda, Praktikum, Visoka strukovna škola za tekstil, Leskovac, 2016.

[31] APHA, Standard methods for the examination of water and wastewater, 20th edition, Franson M.A.H. (ed.), American Public Health Association, Washington, 2000.

[32] D. Marković, G. Petković, Hemija životne sredine, Praktikum, Visoka tehnološko umetnička stukovna škola, Leskovac, 2016.

[33] AOAC - Association of Official Analytical Chemists, Official Methods of Analysis, 20th Edition, AOAC International, 2016.

[34] J.A. Laszlo, Preparing an ion exchange resin from sugarcane bagasse to remove reactive dye from wastewater, Textile Chemists and Colorists, 28(5) (1996) 13-17.

[35] D.Z. Marković Nikolić, G. Petković, N. Ristić, T. Nikolić, A. Zdravković, D. Stojadinović, S. Žerajić, G.S. Nikolić, The green modification of Lagenaria vulgaris agrowaste: spectroscopic and morphological analysis, Zastita Materijala, 60(2) (2019) 197-209.

[36] A. Singh, R.K. Sharma, M. Agrawal, F.M. Marshall, Risk assessment of heavy metal toxicity through contaminated vegetables from waste water irrigated area of Varanasi, Tropical Ecology (India), 51(2S) (2010) 375-387

[37] S. Hena, S. Atikah, H. Ahmad Removal of phosphate ion from water using chemically modified biomass of sugarcane bagasse, International Journal of Engineering Science, 4(1) (2015) 51-62.

[38] M. Taniguchi, H. Suzuki, D. Watanabe, K. Sakai, K. Hoshino, T. Tanaka, Evaluation of pretreatment with Pleurotusostreatus for enzymatic hydrolysis of rice straw, Journal of Bioscience and Bioengineering, 100 (2005) 637-643.

[39] D.J. Cosgrowe, Growth of the plant cell wall, Nature Reviews, 6 (2005) 850-861.

[40] V.S. Chang, M.T. Holtzapple, Fundamental factors affecting biomass enzymatic reactivity, Applied Biochemistry and Biotechnology A, 84-86 (2000) 5-37.

[41] D.Z. Marković, Synthesis of cationic lignocellulosic sorbents and application for the removal of anionic pollutants from water, Doctoral dissertation, University of Niš, Faculty of Sciences and Mathematics, 2018.

[42] F. Xu, J. Yu, T. Tesso, F. Dowell, D. Wang, Qualitative and quantitative analysis of lignocellulosic biomass using infrared techniques: a mini-review, Applied Energy, 104 (2013) 801-809.

[43] R.M. Silverstein, G.C. Bressler, T.C. Morril, Spectrometric identification of organic compounds, 5th ed., John Wiley \& Sons, New Jersey, 2005.

[44] L. Yang, J. Cao, Y. Jin, H. Chang, H. Jameel, R. Phillips, Z. Li, Effects of sodium carbonate pretreatment on the chemical compositions and enzymatic saccharification of rice straw, Bioresource Technology, 124 (2012) 283-291.

[45] K. Kaur, U.G. Phutela, Sodium carbonate pretreatment: an approach towards desilication of paddy straw and enhancement in biogas production, Paddy and Water Environment, 14 (2016) 113-121.

[46] D.Z. Marković Nikolić, M.D. Cakić, G. Petković, G.S. Nikolić, Kinetics, thermodynamics and mechanisms of phosphate sorption onto bottle gourd biomass modified by (3-chloro-2-hydroxypropyl) trimethylammonium chloride, Progress in Reaction Kinetics and Mechanism, 44(3) (2019) 267-285..

[47] X. Li, J. Pan, J. Dai, L. Xu, X. Wei, H. Hang, C. Li, Y. 
$\mathrm{Li}$, Surface molecular imprinting onto magnetic yeast composites via atom transfer polymerization for selective recognition of cephalexin, Chemical Engineering Journal, 198-199 (2012) 503-511.

[48] D. MarkovićNikolić, A. Bojić, D. Bojić, D. Cvetković, M. Cakić, G.S. Nikolić, Preconcentration and immobilization of phosphate from aqueous solutions in environmental cleanup by a new bio-based anion exchanger, Waste and Biomass Valorization, on-line (2018) 1-14, DOI 10.1007/ s12649-018-0401-z.

[49] C. Namasivayam, M.V. Sureshkumar, Removal of chromium(VI) from water and wastewater using surfactant modified coconut coir pith as a biosorbent, Bioresource Technology, 99 (2008) 2218-2225.

[50] D.Z. MarkovićNikolić, A. Bojić, G. Petković, N. Ristić, M. Cakić, G.S. Nikolić, The preparation and utilization of the cationic sorbent based on the surfactant modified bottle gourd shell, Advanced Technologies, 6(2) (2017) 38-50.

[51] P. Loganathan, S. Vigneswaran, J. Kandasamy, Enhanced removal of nitrate from water using surface modification of adsorbents - a review, Journal of Environmental Management, 131 (2013) 363-374.
[52] D.Z. Marković-Nikolić, A.Lj. Bojić, S.R. Savić, S.M. Petrović, D.J. Cvetković, M.D. Cakić, G.S. Nikolić, Synthesis and physico-chemical characterization of anion exchanger based on green modified bottle gourd shell, Journal of Spectroscopy, ID 1856109,(2018) 1-16.

[53] M. Foroughi-dahr, H. Abolghasemi, M. Esmaieli, G. Nazari, B. Rasem, Experimental study on the adsorptive behavior of Congo red in cationic surfactant-modified tea waste, Process Safety and Environmental Protection, 95 (2015) 226-236.

[54] Z. Li, R.S. Bowman, Counterion effects on the sorption of cationic surfactant and chromate on natural clinoptilolite, Environmental Science and Technology, 31(8) (1997) 2407-2412.

[55] R. Tanaka, J. Meadows, P.A. Williams, G.O. Phillips, Interaction of hydrophobically modified (hydroxyethyl) cellulose with various added surfactants, Macromolecules, 25 (1992) 1304-1310.

Izvod

\section{RAZVOJ I KARAKTERIZACIJA RAZNIH KATJONSKIH SORBENATA NA BAZI LIGNOCELULOZNE KORE TIKVICE}

Goran S. Nikolić1, Dragana Z. Marković Nikolić², Miloš M. Kostić3 Miloš Durmišević ${ }^{1}$, Milorad D. Cakić ${ }^{1}$

\footnotetext{
${ }^{1}$ Univerzitet u Nišu, Tehnološki fakultet, Leskovac, Srbija

${ }^{2}$ Visoka tehnološko umetnička strukovna škola, Leskovac, Srbija

${ }^{3}$ Univerzitet u Nišu, Prirodno-matematičkifakultet, Departman za hemiju, Niš, Srbija
}

Cilj ove studije je razvoj različitih katjonskih sorbenata na bazi lignocelulozne biomase ploda Lagenaria vulgaris, sa svojstvom efikasne sorpcije anjonskih polutanata iz vodenih rastvora. U tom smislu, za sintezu katjonskih sorbenata ispitana je i korišćena lignocelulozna kora tikvice (LGS biomasa), koja predstavlja potencijalno dragoceni poljoprivredni otpad. Priprema odgovarajućeg prekursora sinteze (LVAT) izvršena je alkalnim predtretmanom LGS biomase. Predtretman biomase u slabo alkalnim uslovima, pomoću zelenog karbonatnog rastvora, izvođen je radi delimične delignifikacije i ekstrakcije depolimerizovane hemiceluloze. Na ovajnačin se postiže veća poroznost materijala i aktiviranje dostupnih celuloznih mikrofibrila, što je od značaja za efikasniju sintezu sorbenta većeg afiniteta i sorpcionog kapaciteta za anjonske vrste. Aktivacija podrazumeva prevođenje raspoloživih $-\mathrm{OH}$ funkcionalnih grupa do -ONa forme (alkali-celuloza), uz održanje polazne konstitucije biomase. Aktivirani prekursor je pogodniji za uspešnije izvođenje reakcije eterifikacije organskim halogenidom, a potom katjonizovanja odgovarajućim $\mathrm{N}$ reagensima. Sinteza katjonskih sorbenata vršena je na tri načina. Za katjonsku modifikaciju LGS biomase i LVAT prekursora, korišćeni su različiti N-reagensi, poput tercijarnih amino i kvaternernih amonijum jedinjenja, radi utvrđivanja uticaja strukture i hidrofobnosti reagensa na ishod sinteze, a pre svega na sorpciona svojstva dobijenih sorbenata. Sintetisani katjonski sorbenti su okarakterisani fizičkohemijskim metodama i testirani za uklanjanje anjonskih polutanata iz vode, pre svega fosfata i nitrata. Različite hemijske modifikacije lignocelulozne biomase primenjene u ovim istraživanjima pružaju naučni doprinos boljem razumevanju samog mehanizma procesa sorpcije anjona na površini sorbenta.
(ORIGINALNI NAUČNI RAD) UDK 662.63:547.458.84:628.193

Ključne reči: biomasa, kora tikvice, katjonski sorbenti, anjonski polutanti, tretman otpadnih voda 